\title{
Monimenetelmällinen näkökulma omaehtoisen opiskelun hyötyihin
}

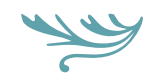

Kymmenessä Euroopan maassa tehty tutkimus osoittaa, että omaehtoinen opiskelu parantaa elämänlaatua monella tapaa. Esimerkiksi opiskelijan lisääntynyt usko omiin vaikuttamismahdollisuuksiin johtaa muutoksiin terveyskäyttäytymisessä. Tunne kuulumisesta johonkin yhteisöön oli vastaajille tärkeää.

\section{BELL-TUTKIMUKSEN TAUSTA JA TAVOITTEET}

ARTIKKELI POHJAUTUU Benefits of Lifelong Learning -projektin (BeLL'; www.bell-project.eu) päätuloksiin. Projektissa kerättiin kymmenessä ${ }^{2} \mathrm{Eu}-$ roopan maassa kysely- ja haastatteluaineisto, jonka avulla tutkittiin, minkälaisia ns. laajempia hyötyjä (wider benefits, ks. Schuller \& Desjardins 2010) omaehtoiseen nonformaaliin ei-ammatilliseen koulutukseen osallistuvat aikuiset saavat opiskelusta. Suomessa kyseisen tyyppisiin opintoihin on helppo viitata vapaan sivistystyön käsitteellä, mutta selkeän englanninkielisen käsitteen puuttuminen vaikeuttaa vertailevaa tutkimusta ja koulutusyhteistyötä. Eiammatillisen aikuiskoulutuksen määrittely negaation kautta on yleinen, mutta hankala tapa (Eurydise
2007, 7). Pohjoismainen vapaan sivistystyön käsite ja toimintamalli ei täysin kata koko nonformaalin ei-ammatillisen koulutuksen kirjoa, ja sen kohdalla ongelmana on myös kaksi erilaista käännöstä, eli ruotsalaisten pääsääntöisesti käyttämä popular (esim. Nordvall 2002, 16; Rubenson 2006, 337; Laginder, Nordvall \& Crowther 2013) ja suomalaisten useammin käyttämä liberal (esim. Manninen 2010a), joka on useammin käytössä myös EU:ssa (esim. Eurydise 2007, 13; Litster, Brooks \& Burton 2010, 44). Englanninkielisessä kirjallisuudessa käsitettä liberal käytetään yleisesti merkityksessä "ammatillisen koulutuksen vastakohta" (Jarvis \& Criffin 2003; Jarvis 2014; Sutcliffe 2014) mikä pohjautuu antiikin kreikan vapaiden taiteiden (artes liberales) ideaan. Hyvä 
perusmääritelmä ei-ammatillisille opinnoille voisi olla Micarin (2003, 27-28) kuvaus opinnoista, joissa 'ei ensisijaisesti opiskella työhön liittyviä taitoja, vaan älyllisen kasvun tuoman mielihyvän ja [..] tietämisen itseisarvoisen merkityksen takia'.

Selkeän käsitteistön puuttuminen näkyy myös vapaan sivistystyön kirjavissa ja osin olemattomissa rakenteissa (esimerkiksi Italia), tutkimuksessa ja tilastoinnissa (ks. Eurydise 2007). Esimerkiksi Euroopan kattavissa osallistumistilastoissa ei ole selkeästi eroteltu ei-ammatillista ja ammattiin liittyvää nonformaalia koulutusta. Tilastoista (Adult Education Survey 2007, Boateng 2009) voi yrittää päätellä, että koska 80 \% nonformaalista aikuiskoulutuksesta Euroopassa on työhön liittyvää, voisi jäljelle jäävä $20 \%$ olla eiammatillista. Suomessa ei-ammatilliseen koulutukseen osallistumista on kysytty jo vuosikymmeniä Tilastokeskuksen aikuiskoulutustutkimuksessa, ja se on pysynyt lähes ennallaan (naisista vapaan sivistystyön opintoihin osallistuu 24-26\%, miehistä 10-11\%).

Nonformaali ei-ammatillinen koulutus unohdetaan tilastojen ja koulutuspolitiikan lisäksi usein myös tutkimuksissa. Esimerkiksi laajempia hyötyjä on tutkittu pääasiassa formaalin koulutuksen tuottamina lähinnä taloudellisina hyötyinä, mutta nonformaalin koulutuksen sosiaalisia ja henkilökohtaisia hyötyjä on tutkittu huomattavasti vähemmän (Desjardins 2003, 13 ja 16; Hammond 2005, 241; Feinstein \& Budge 2007,21).

BeLL on ensimmäinen useampia maita kattava tutkimus erityisesti nonformaalin ei-ammatillisen koulutuksen hyödyistä. BeLL pohjautuu kotimaiseen vapaan sivistystyön hyötyjä kartoittaneeseen tutkimukseen (Manninen \& Luukannel 2008; Manninen 2010a ja b).

Artikkelissa kuvataan BeLL-tutkimuksen päätulokset sekä määrällisen $(n=8646)$ että laadullisen aineiston (4 443 vastaajan avovastausten ja 82 teemahaastattelun laadullisen sisällönanalyysin) pohjalta. Teemahaastatteluiden analyysi toteutettiin samalla tavalla kuin avovastausten analyysi, joten sitä ei erikseen raportoida tässä artikkelissa (ks. Sgier 2014). Teemahaastatteluiden tulokset olivat identtisiä avovastausten analyysin tulosten kanssa. Artikkelissa kuvataan monimenetelmällisen lähestymistavan (mixed methods, Hammond 2005) etuja tämän tyyppisessä tutkimuksessa.

\section{AIKAISEMPIA TUTKIMUKSIA}

Koulutuksen hyötyjä on tutkittu pääasiassa formaalin koulutuksen osalta ja tilastollisesti esimerkiksi vertailemalla koulutus- ja tulotasoja. Nonformaalin koulutuksen ja erityisesti nonformaalin ei-ammatillisen aikuiskoulutuksen osalta tutkimustietoa on vähemmän (Motschilnig 2012). Aikuiskoulutuksen alueella sosiaalisia ja yksilöllisiä hyötyjä on tutkittu lähinnä OECD:n (2007; 2010), Lontoon yliopiston (esim. Feinstein, Budge, Vorhaus \& Duckworth 2008) ja Britannian kansallisen aikuiskoulutusorganisaation (NIACE) toimesta (Schuller \& Watson 2009). Suomessa vapaan sivistystyön hyötyjä ovat kartoittaneet Manninen ja Luukannel (2008; Manninen 2010b).

Hyviä yhteenvetoja koulutuksen hyödyistä ovat koonneet Field (2009), Motschilnig (2012) ja Feinstein ym. (2008). Tutkimusten mukaan koulutukseen osallistuminen lisää fyysistä ja henkistä hyvinvointia, sosiaalista osallistumista ja verkostoja, itseluottamusta, opiskelutaitoja ja opiskelumotivaatiota. Osallistuminen myös parantaa vanhemmuuteen ja kansalaisuuteen liittyviä taitoja, minäkuvaa, luottamusta omiin kykyihin ja elämänhallinnan tunnetta. Yhteisötasolla koulutus edistää sosiaalista koheesiota ja sosiaalista pääomaa (Côté 2005), koska se lisää luottamuksen tunnetta, suvaitsevaisuutta, yhteisöllisyyttä ja poliittista aktiivisuutta.

Terveystieteissä on todennettu koulutuksen ja terveydentilan, terveyskäyttäytymisen ja hyvinvoinnin yhteys esimerkiksi tupakoinnin ja alkoholinkäytön vähentymisenä (Feinstein \& Hammond 2004).

Monet tutkimustulokset pohjautuvat korrelaatioihin osallistumisen ja jonkun ominaisuuden välillä, mutta joukossa on myös tutkimuksia, joissa syy-seurausyhteyttä on arvioitu tarkemmin. Preston \& Feinstein (2004) löysivät yhteyden aikuiskoulutukseen osallistumisen ja poliittisen aktivoitumisen ja Field (2005) vastaavasti yhteisöön osallistumisen välille. Hyödyt näyttävät heijastuvan myös yhteisön hyvinvoinnin tasolle (Merriam \& Kee 2014). 


\section{BELL-TUTKIMUKSEN TOTEUTUS}

Tutkimusasetelma pohjautui aikaisempaan kotimaiseen tutkimukseen (Manninen \& Luukannel 2008) ja siinä käytettyyn monimenetelmälliseen lähestymistapaan (Hammond 2005; Mason 2006). BeLL-aineisto kerättiin kyselylomakkeella ( $n=8646$ ), jossa oli sekä Likert-asteikollisia koettua muutosta mittaavia väittämiä että kaksi avointa kysymystä, joissa vastaajia pyydettiin kuvailemaan osallistumisen aikaansaamia muutoksia ja vaikutuksia. Lisäksi tehtiin 82 teemahaastattelua eri maissa.

\section{Teoreettiset käsitteet}

Kyselylomakkeen väittämät valittiin aikaisempien tutkimusten pohjalta. Tavoitteena oli saada kattava kokonaiskuva aikuisopiskelun laajemmista hyödyistä, joita aikaisemmin on tutkittu pienempien, tiettyyn teemaan kohdentuvien tutkimusten avulla, esimerkiksi perhehyötyjen (Brasset-Grundy 2004) tai terveyskäyttäytymisen (Feinstein \& Hammond 2004) näkökulmasta. Potentiaaliset hyödyt määriteltiin lopulta 14 teoreettisen hyötykäsitteen avulla, ja niissä tapahtunutta koettua muutosta mittaamaan kehitettiin 35 väittämää (ks. taulukko 4).

Yleistä suhtautumistapaa omiin koettuihin vaikutusmahdollisuuksiin mitattiin psykologisissa tutkimuksissa kehitettyjen mittareiden avulla. Rotterin (1966) kontrolliodotus (Locus of Control) kuvaa yksilön kokemusta siitä, miten paljon hän voi vaikuttaa erilaisiin tapahtumiin (Zimbardo 1985, 275). Kyse ei ole elämänhallinnasta konkreettisesti, vaan suhtautumistavasta, jolla yksilö eri tilanteissa reagoi vastoinkäymisiin ja valintatilanteisiin. Toinen psykologinen käsite on minäpystyvyys (Self-efficacy), joka kuvaa luottamusta omaan kykyyn olla oman elämän aktiivinen toimija (Cervone, Artisitco \& Berry 2006).

Suvaitsevaisuuden (Tolerance) käsitteen avulla arvioitiin muutoksia, joita opiskelu mahdollisesti saa aikaan suhtautumisessa omista poikkeaviin tapoihin, mielipiteisiin, käytäntöihin tai uskomuksiin (Field 2009). Myös luottamuksen (Trust; Kouvo 2011; Newton \& Zmerli 2011) lisääntyminen kanssaihmisiä ja yhteiskunnan instituutioita kohtaan rakentaa sosiaalista pääomaa ja sosiaalista koheesiota, joten sillä on merkittävä rooli koulutuksen yhteiskunnallisten hyötyjen näkökulmasta (OECD 2007, 80; Merriam \& Kee 2014). Luottamuksen lisääntymistä selittää koulutuksen aikana syntyvät tai vahvistuvat sosiaaliset verkostot eli sosiaalinen vuorovaikutus, muiden ihmisten tapaaminen, uudet ystävät ja verkostot (Field 2009; Schuller ym. 2002).

Aktiivista kansalaisuutta mittaava yhteiskunnallinen osallistuminen (Civic and social engagement) korreloi koulutustason kanssa (Merriam \& Kee 2014). Siihen sisältyy esimerkiksi järjestöissä toimiminen, vapaaehtoistyö ja aktiivinen rooli omassa lähiyhteisössä (OECD 2007). Se vaatii myös kansalaisvalmiuksia (Civic competence) eli taitoja ja tietoa poliittiseen päätöksentekoon, järjestötoimintaan, kokouskäytäntöihin ja oman mielipiteen esille tuomiseen liittyvistä asioista (Hoskins \& Crick 2010, 8).

Elämän tarkoituksellisuus (Sense of Purpose in Life) rakentuu elämäntavoitteiden ja tulevaisuuden odotusten pohjalle tunteeseen, että elämällä on merkitys, tarkoitus ja tavoitteet (Ryff 1989). Tutkimusten mukaan se ennustaa henkistä hyvinvointia, joka muodostuu mielenterveydestä, onnellisuudesta, elämään tyytyväisyydestä ja elämänlaadusta. Koulutukseen osallistumisen on todettu lisäävän henkistä hyvinvointia erityisesti lisääntyneen sosiaalisen vuorovaikutuksen ja yhteisöön osallistumisen kautta (Field 2009; Makola \& van den Berg 2008; Manninen \& Luukannel 2008).

Fyysisen terveydentilan mittaamiseen käytettiin itsearviointia (self-rated health), joka on yleisesti käytetty ja toimivaksi todettu mittari terveydentilasta (Chen \& Yang 2014, 65; Nummela, Sulander, Karisto \& Uutela 2009). Terveyskäyttäytymisen käsite mittaa konkreettisia käyttäytymisen muutoksia, kuten tupakoinnin ja alkoholinkäytön vähenemistä, liikunnan lisääntymistä ja terveellisempien elämäntapojen omaksumista (Feinstein \& Hammond 2004).

Vaikka vapaan sivistystyön opintoihin osallistutaan pääsääntöisesti muista kuin ammatillisista syistä, tuottavat ne myös työhön liittyviä hyötyjä (Manninen \& Luukannel 2008). Näitä ovat esimerkiksi urasuunnitelmien selkiytyminen, työmahdollisuuksien lisääntyminen ja lisätulojen hankkimismahdollisuus esimerkiksi käsitöitä myymällä tai itse kouluttajana toimimalla. Perheeseen liittyvät hyödyt kuvaavat 
vanhempien lisääntynyttä kiinnostusta ja kykyä tukea lastensa koulunkäyntiä (Brasset-Grundy 2004).

Muutokset koulutuskokemuksissa liittyvät opiskelumotivaatioon, opiskelijaminäkuvaan, aikuiskoulutuksen arvostukseen ja halukkuuteen kertoa opiskelumahdollisuuksista myös ystäville ja sukulaisille. Väittämien pohjana käytettiin osallistumis- ja motivaatiotutkimuksia (Rubenson 1979; Manninen 2004; Pintrich 1988).

Laadullisen aineiston (avokysymykset ja haastattelut) sisällönanalyysissa käytettiin lisäksi käsiteparia taidot ja kompetenssit, mutta siitä ei tehty kyselylomakkeelle väittämiä käytännön syistä. Kaikkien potentiaalisten taitojen listaaminen vastausvaihtoehdoiksi ei olisi ollut mahdollista.

\section{Hyötyjä mittaavat avokysymykset ja strukturoidut väittämät}

Kyselylomakkeen alussa vastaajia pyydettiin kuvaamaan 1-3 ei-ammatillista kurssia, joille he ovat osallistuneet viimeisten 12 kuukauden aikana (kurssin nimi, aihe, kesto ja järjestäjä). Kysymyksen tavoitteena oli varmistaa, että vastaaja kuuluu kohderyhmään (kyseisiä opintoja vuoden aikana suorittaneet) ja samalla palauttaa vastaajaan mieleen opiskelukokemukset.

Tämän jälkeen vastaajia pyydettiin kuvailemaan omin sanoin opiskelun aikaansaamia vaikutuksia ja muutoksia kahdella avokysymyksellä. Tavoitteena oli saada esille vastaajan omat kokemukset ja omasanainen kuvaus mahdollisista muutoksista ja hyödyistä, joita opiskelu on saanut aikaan ilman, että myöhemmin lomakkeessa esitettävät strukturoidut väittämät ohjaisivat vastaajan ajattelua. Suomenkielisessä lomakkeessa kysymykset esitettiin seuraavassa muodossa:

2. Muistele nyt edellä Kuvaamiasi vapaan sivistystyön kursseja, ja vastaa seuraaviin kysymyksiin tämän edellisen lukuvuoden aikana tapahtuneen osallistumisesi ja opiskelukokemustesi pohjalta mahdollisimman tarkkaan ja laajasti.

2.1 Minkälaisia välittömiä seurauksia ja vaikutuksia kursseille osallistumisella on ollut sinulle?

2.2 Mitä muita seurauksia, pitkän aikavälin vaikutuksia tai muutoksia olet huomannut?
Avokysymysten jälkeen vastaajia pyydettiin arvioimaan kursseille osallistumisen aikaansaamia koettuja muutoksia seitsemänportaisella asteikolla. Väittämät (35 kappaletta, katso taulukko 4) mittasivat edellä kuvattuja teoreettisia käsitteitä. Kysymys muotoiltiin seuraavasti:

2.3.1 Muistele taas edellä kuvaamiasi noin 12 viime kuukauden aikana käymiäsi vapaan sivistystyön piiriin luettavia kursseja. Arvioi, ovatko nämä kurssit saaneet aikaan muutoksia elämässäsi alla kuvatuissa asioissa.

Käytä asteikkoa: paljon vähemmän (- -) vähemmän (- ) hieman vähemmän (-) ei muutosta (0) hieman enemmän $(+)$ enemmän $(++)$ paljon enemmän (+++)

Muutosasteikon käytölle oli useita perusteita. Ensinnäkin se mahdollisti myös koulutuksen mahdollisten negatiivisten vaikutusten arvioinnin, jota on harvoin tehty (Feinstein ym. 2008, 20). Toinen syy oli tavoite arvioida nimenomaan koulutuksen aikaansaamaa muutosta suhteutettuna vastaajan lähtötasoon. Näin pyrittiin välttämään osallistumisen kasautumisen aiheuttama korrelaatioharha eli vääristymä. Se saattaa syntyä tuloksiin, jos osallistumisen ja erilaisten ominaisuuksien yhteyttä tarkastellaan vain korrelaatiotasolla jo ennestään hyvinvoivien ja motivoituneiden aikuisopiskelijoiden ryhmässä. BeLL-tutkimuksessa laajemmat hyödyt on siis määritelty 'vastaajien kokemiksi positiivisiksi muutoksiksi', ja mittari ottaa näin myös huomioon vastaajien erilaisen lähtötason. Esimerkiksi ennen osallistumista hankalammassa elämäntilanteessa ollut saattaa kokea hyvinvoinnissa suuremman muutoksen kuin sellainen, jolla elämäntilanne on jo lähtötilanteessa helpompi.

\section{Kohderyhmä ja otanta}

Kyselyn kohderyhmä olivat aikuiset, jotka ovat osallistuneet viimeisten 12 kuukauden aikana nonformaaliin ei-ammatilliseen koulutukseen eli suomalaisittain vapaan sivistystyön tyyppisiin opintoihin. Satunnaisotanta aikuisopiskelijoista ei ollut mahdollinen, koska eri maissa hyvin erityyppisissä eiammatillisia opintoja tarjoavissa järjestöissä ja koulutusorganisaatioissa opiskelevista aikuisista ei ole 
käytettävissä osallistujarekistereitä. Ainoa mahdollinen otantamenetelmä oli siis tarkoituksenmukainen eli mukavuusotanta (convenience sampling; Hedt \& Pagano 2010), jossa kysely suunnattiin omaehtoisia ei-ammatillisia opintoja vuoden aikana suorittaneille aikuisille. Vastaava otantahaaste esiintyy yleensä lääketieteellisissä tutkimuksissa, joissa halutaan tavoittaa tiettyyn toimenpiteeseen tai palveluun osallistuneita henkilöitä (Sudman, Sirken \& Cowan 1988). Haastateltavien valinnassa käytettiin samaa periaatetta sillä lisäyksellä, että valinnassa kiinnitettiin huomiota taustoiltaan erilaisten osallistujien valintaan.

Kysely toteutettiin kunkin maan kielellä sekä sähköisellä että paperilomakkeella. Kutsua osallistua tutkimukseen levitettiin sähköisesti, paperikirjeillä ja ilmoituksilla kansallisten kattojärjestöjen kautta koulutusorganisaatioille, jotka tiedottivat edelleen opiskelijoita ilmoitustaulujen ja sähköisten kanavien kautta. Suomessa kyselystä tiedotettiin Vapaan sivistystyön yhteisjärjestön kautta eri alajärjestöille, esimerkiksi Kansalaisopistojen liitolle, jotka tiedottivat siitä edelleen omille organisaatioilleen, esimerkiksi Kansalaisopistoille ja Kesäyliopistoille. Lisäksi tutkijat jakoivat lomakkeita infopisteisiin ja suoraan opiskelijoille.

Käytännössä vastaajat edustavat aktiivisten aikuisopiskelijoiden ryhmää, eli mukaan on valikoitunut henkilöitä, jotka ovat osallistuneet edeltävien 12 kuukauden aikana vähintään yhdelle ei-ammatilliselle kurssille, on tavoitettu joko koulutusorganisaation tai tutkijoiden kautta ja ovat olleet halukkaita osallistumaan tutkimukseen. Vaarana hyötytutkimuksissa saattaa olla, että tutkimukseen valikoituu enemmän sellaisia henkilöitä, joilla on tavallista enemmän positiivisia tai negatiivisia opiskelukokemuksia (ks. Hammond 2005, 243 ja 249), joten tulosten tarkastelussa on hyvä pitää mielessä tämä virhemahdollisuus. Aineiston analyysissa tätä arvioitiin vastausprofiilien, avovastausten luonteen ja teemahaastatteluiden avulla, mutta vastaajien valikoitumista ei ollut selvästi havaittavissa. Lisäksi vertailtiin mahdollisuuksien mukaan vastaajaprofiileja eri maissa perusjoukokkoa kuvaaviin tietoihin, jos sellaisia oli saatavilla: esimerkiksi suomalaisten vastaajien profiili vastaa hyvin vapaan sivistystyön tilastoituja osallistu- jarakenteita sekä organisaatiomuotojen että taustamuuttujien osalta.

Riittävän kattavasti täytettyjä lomakkeita saatiin yhteensä 8646 kohderyhmäkriteerit täyttävältä vastaajalta, jotka jakautuivat suhteellisen tasaisesti eri maiden kesken (taulukko $\mathbf{1}$ ).

Vastaajaprofiili vastaa hyvin Suomalaisen vapaan sivistystyön osallistujarakenteita: $71 \%$ vastaajista oli naisia (Suomessa 70 \% osallistujista on naisia; Kumpulainen 2008, 94). Ikäjakauma vaihteli 15 ja 92 vuoden välillä (keskiarvo 45,3, hajonta 16,8 vuotta) ja koulutustaso oli suhteellisen korkea: 37,6 \% oli korkeakoulututkinto (ISCED 5-6), toiseksi suurin vastaajaryhmä $(32,2 \%)$ olivat ylemmän toisen asteen koulutuksen suorittaneet (ISCED 3, Suomessa lukio tai ammattikoulu).

Vastaajista $62 \%$ oli osallistunut vain yhdelle kurssille, muut useammalle. Vastaajat olivat suorittaneet yhteensä 14063 kurssia, joiden aiheet teemoiteltiin kurssin nimen ja aiheen pohjalta 25 kategoriaan, jotka vastasivat hyvin suomalaista vapaan sivistystyön oppilaitosten kurssitarjontaa. Mielenkiintoista olikin, että kymmenessä maassa nonformaalin eiammatillisen aikuiskoulutuksen sisällöt ovat lähes identtiset pieniä kansallisia painotuksia lukuun ottamatta $^{3}$, vaikka organisaatiorakenteet vaihtelevat suuresti maittain. Yleisimmät kurssiaiheet olivat kielet (2 478 kurssia) ja liikunta (1 669), harvinaisempia tiedeaiheet (84), eläinharrastukset (76) ja peruslaskutaitoja kehittävät kurssit (27).

\begin{tabular}{|l|r|r|}
\hline MAA & $\mathrm{n}$ & \multicolumn{1}{c|}{$\%$} \\
\hline Englanti & 709 & 8.2 \\
\hline Suomi & 1252 & 14.5 \\
\hline Saksa & 902 & 10.4 \\
\hline Italia & 543 & 6.3 \\
\hline Romania & 1043 & 12.1 \\
\hline Sveitsi & 274 & 3.2 \\
\hline Serbia & 981 & 11.3 \\
\hline Espanja & 898 & 10.4 \\
\hline Tsekki & 989 & 11.4 \\
\hline Slovenia & 1055 & 12.2 \\
\hline Yhteensä & $\mathbf{8 6 4 6}$ & $\mathbf{1 0 0 . 0}$ \\
\hline
\end{tabular}

Taulukko 1.

Vastaajat maittain 
Suomessa enemmistö vastaajista (70 \%) oli opiskellut kansalaisopistossa, $22 \%$ opintokeskusten tai järjestöjen kursseilla, 4 \% kesäylipistoissa ja $9 \%$ kansanopistoissa. Vastaajamäärät vastaavat varsin hyvin kyseisten oppilaitostyyppien tilastoituja osallistujamääriä.

\section{PÄÄTULOKSET}

\section{Tilastollinen analyysi ja faktorirakenne}

Vastausten frekvenssijakaumien ${ }^{4}$ tarkastelu osoitti, että vastaajat olivat kokeneet useita osallistumisen aikaansaamia positiivisia muutoksia. Vastaajista 70$87 \%$ koki omaavansa nyt hieman enemmän, enemmän tai paljon enemmän opiskelumotivaatiota ja sosiaalisia verkostoja ja hyvinvointinsa lisääntyneen. Vähemmän muutoksia oli tapahtunut esimerkiksi työhön ja uraan sekä aktiiviseen kansalaisuuteen liittyvissä asioissa, mutta näissäkin 31-42\% oli kokenut myönteistä muutosta.

Aluksi koettujen hyötyjen teoreettista rakennetta testattiin konfirmatorisen faktorianalyysin avulla. Konfirmatorisen faktorianalyysin edellytyksenä on teoriaan perustuva ennakkokäsitys faktoreista, niille latautuvista muuttujista sekä faktoreiden välisestä korrelaatiosta, joita voidaan testata empiirisen aineiston avulla. Tässä tutkimuksessa testattiin kunkin ulottuvuuden osalta erikseen, pitääkö teoriaan perustuva oletus koulutukseen osallistumisen hyödyistä paikkansa. Kun konfirmatorinen faktorianalyysi on teorialähtöinen ja teorian testaamiseen käytetty menetelmä, eksploratiivinen faktorianalyysi on aineistolähtöinen eikä sen käyttö edellytä ennakko-oletusta aineiston faktorirakenteesta (Brown 2006). Konfirmatorisen faktorianalyysin jälkeen hyötyjä ja niiden välisiä suhteita analysoitiin myös rakenneyhtälömallittamisen avulla (Structural Equation Modelling, SEM), mutta SEM-malli ja siihen pohjautuvat tulokset esitetään toisaalla (Manninen, Kil, Thöne-Geyer, Meriläinen, Sgier, Mallows \& Fleige [arvioitavana]).

Hyötyjä kuvaavat faktorit (taulukko 2; väittämät esitetty taulukossa 4) noudattavat varsin hyvin artikkelin alussa kuvattuja teoreettisia käsitteitä, mutta eivät kaikilta osin. Muutamia väittämiä siirrettiin toisen faktorin (käsitteen) alle, ja joitakin väittämiä poistettiin analyysista heikon kommunaliteetin takia. Suurin muutos oli sosiaalisten verkostojen, luottamuksen ja yhteiskunnallisen osallistumisen latautuminen yhdeksi faktoriksi, joka nimettiin sosiaaliseksi osallistumiseksi. Myös fyysistä terveydentilaa ja terveyskäyttäytymistä mittaavat väittämät latautuivat yhdelle terveys-faktorille. Taulukossa 2 esitettyjen summamuuttujien korrelaatio vaihteli .16-.79 välillä.

Taulukko 2. Omaehtoisen opiskelun hyötyjä kuvaavat faktorit ja niille latautuneiden väittämien summamuuttujat.

\begin{tabular}{|l|c|c|c|}
\hline & Cr.a (n) & ka. & kh. \\
\hline Elämänhallinta (3 väittämää) & $.85(8066)$ & 5.11 & 1.05 \\
\hline Minäpystyvyys (3 väittämää) & $.85(8044)$ & 5.04 & 1.05 \\
\hline Elämän tarkoituksellisuus (2 väittämää) & $.78(8170)$ & 5.40 & 1.10 \\
\hline Suvaitsevaisuus (2 väittämää) & .80 (8147) & 5.60 & 1.12 \\
\hline Sosiaalinen osallistuminen (5 väittämää) & $.78(7717)$ & 5.07 & .99 \\
\hline Muutokset koulutuskokemuksissa (4 väittämää) & $.80(7975)$ & 5.75 & .93 \\
\hline Terveys (3 väittämää) & $.84(8056)$ & 5.35 & 1.19 \\
\hline Henkinen hyvinvointi (2 väittämää) & $.82(8134)$ & 5.47 & 1.11 \\
\hline Työ (2 väittämää) & $.77(7475)$ & 4.44 & 1.33 \\
\hline Perhe (2 väittämää) & $.89(2735)$ & 5.43 & 1.31 \\
\hline
\end{tabular}

\section{Asteikko:}

paljon vähemmän (1) vähemmän (2) hieman vähemmän (3) ei muutosta (4) hieman enemmän (5) enemmän (6) paljon enemmän (7)

Summamuuttujissa puuttuvat tiedot on korvattu vastausten keskiarvolla [MEAN(item 1.item2.item3.item4)]

Cronbachin $\alpha$ on laskettu poistamalla puuttuvia tietoja sisältävät vastaukset

Kaikkien summamuuttujien vaihteluväli on 1-7 (Min.-Max.) 


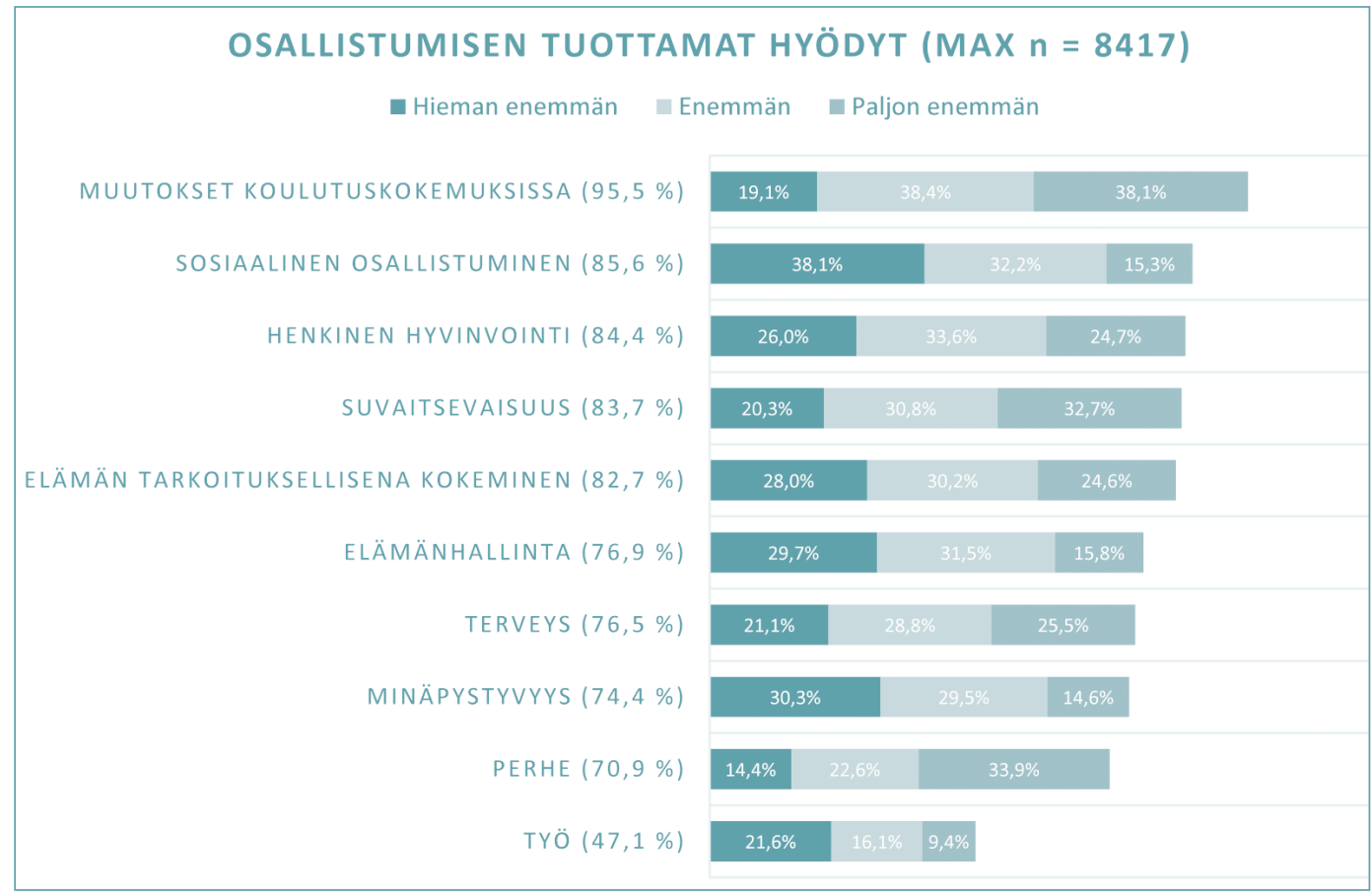

Kuvio 1. Osallistumisen tuottamat koetut hyödyt.

Kaksi terveyskäyttäytymiseen liittyvää eli tupakoinnissa ja alkoholinkäytössä tapahtunutta muutosta arvioivaa väittämää analysoidaan myöhemmin erikseen.

Osallistumisen tuottamia koettuja hyötyjä voi parhaiten tarkastella positiivista muutosta kuvaavien frekvenssijakaumien avulla. Kuvioon 1 on poimittu niiden vastaajien prosenttiosuudet, jotka ovat kokeneet positiivista muutosta (hieman enemmän, enemmän tai paljon enemmän) faktoreiden pohjalta muodostettujen summamuuttujien mukaan. Tarkastelua varten summamuuttujat skaalattiin takaisin kokonaisluvuiksi $1-7.5$

Suurimpina hyötyinä nousevat siis esiin opiskelumotivaation ja koulutuksen arvostamisen lisääntyminen eli positiiviset muutokset koulutuskokemuksissa, joita yhteensä $96 \%$ vastaajista tunnistaa tapahtuneen omalla kohdallaan. Koulutus näyttäisi myös lisäävän sosiaalista osallistumista yhteensä 86 \% kohdalla; vastaajista 38 \% kokee sitä olevan koulutukseen osallistumisen jälkeen hieman enemmän, 32 $\%$ enemmän ja 15 \% paljon enemmän. Hieman alle puolet kokee myös saaneensa työhön ja uraan liittyviä hyötyjä vapaan sivistystyön opinnoista. Tulokset ovat linjassa aikaisemman kotimaisen (Manninen \& Luukannel 2008) ja muiden tutkimusten kanssa.

\section{Avovastausten laadullinen analyysi}

Kahteen hyötyjä ja muutoksia mittaavaan avokysymykseen saatuja vastauksia sekä teemahaastatteluja analysoitiin laadullisen sisällönanalyysin (Gläser \& Laudel 2013) ja avoimen, systemaattisen koodauksen (Saldana 2013) avulla. Avovastausten analyysi tehtiin 4443 vastaajan osalta niin, että maittain analysoitiin vähintään 400 ensimmäisen vastaajan kaksi avovastausta. Avovastauksia siis analysoitiin yhteensä 8886 kappaletta.

Analyysiyksikkö oli avovastauksesta paikannettu lausuma, jossa on mainittu yksi hyöty (esim. "erityisesti ilahduttavat kieliopinnot", "keeps my mind active", katso taulukko 3). Tällaisia lausumia paikannettiin analyysissa yhteensä 10366 , ja ne teemoiteltiin 50 hyödyn (esimerkiksi henkinen hyvinvointi) ja 19 taidon alle (esimerkiksi kielitaito). 


\begin{tabular}{|c|c|c|}
\hline ESIMERKKEJÄ VASTAUKSISTA & LAUSUMAT & TEEMAT \\
\hline \multirow{4}{*}{$\begin{array}{l}\text { I have learnt some things to apply to my hobby } \\
\text { of horse keeping that improves the quality of my } \\
\text { life [..]. It keeps my mind active, and improves } \\
\text { my wellbeing by giving me goals to achieve. } \\
\text { (ENG_open_100003) }\end{array}$} & learnt some things to apply to my hobby & taidot (ei tarkennettu) \\
\hline & improves the quality of my life & elämänlaatu \\
\hline & keeps my mind active & henkinen hyvinvointi \\
\hline & improves my wellbeing & arjessa jaksaminen \\
\hline \multirow{4}{*}{$\begin{array}{l}\text { Olen saanut vireyttä viikon arkipäiviin. } \\
\text { Sosiaaliset kontaktit lisääntyneet sopivasti, kun } \\
\text { jäin eläkkeelle osin asiakaspalvelusta. Erityisesti } \\
\text { ilahduttavat kieliopinnot esim espanjassa ja } \\
\text { saksassa, joita kieliä käytän eniten monilla } \\
\text { matkoillani vuoden mittaan talvisin ja syksyisin. } \\
\text { (FIN_open_200391) }\end{array}$} & giving me goals to achieve & opiskeluhalukkuus \\
\hline & saanut vireyttä & arjessa jaksaminen \\
\hline & sosiaaliset kontaktit lisääntyneet & sosiaalinen vuorovaikutus \\
\hline & erityisesti ilahduttavat kieliopinnot & kielitaito \\
\hline
\end{tabular}

Taulukko 3. Esimerkki avovastauksista ja niiden analyysista.

Analyysi eteni vaiheittain paikantamalla ja teemoittelemalla hyötyjä kuvaavat lausumat. Ensimmäinen 200 vastaajan analyysi tuotti 42 hyötyteemaa (esim. sosiaalinen vuorovaikutus) ja 14 taitoa (esim. kielitaito). Jatkokoodausta varten tehtiin koodausohje, jossa teemat määriteltiin esimerkkeineen, sekä Excel-pohja, johon syötettiin eri maiden avovastaukset ja koodausrunko. Analyysi kattoi lopulta vähintään 400 ensimmäisen vastaajan kahden avokysymyksen vastaukset maittain, yhteensä 4443 vastaajaa. Tässä vaiheessa ei enää löydetty uusia teemoja, eli ns. saturaatiopiste (Strauss \& Corbin 1998, 136) saavutettiin. Jokaisessa maassa käytettiin kahta rinnakkaiskoodaajaa, ja koodauksia tarkistettiin myös ristiin eri maiden välillä.

Koodauksessa käytetty Excel-pohja mahdollisti myös analyysissa löydettyjen hyötyjen kvantifioinnin. On käyty paljon keskustelua (ks. Silverman 1993, 51-52) siitä, saako laadullisen analyysin yhteydessä laskea löydettyjen teemojen frekvenssejä ja ylipäätään määrällistää laadullisia tuloksia. Kvantifiointia voi puolustaa sellaisissa tapauksissa, joissa laadullinen aineisto on riittävän iso, ja löydettyjen teemojen yleisyyden tarkastelu tuo jotain lisäarvoa ja ymmärrystä tutkittavasta ilmiöstä. Esimerkiksi BeLLanalyysissa voitiin osoittaa, että yleisin spontaanisti mainittu hyöty oli opiskeluhalukkuuden lisääntyminen, jonka oli maininnut 10,6 \% vastaajista. Löydettyjen laadullisten teemojen frekvenssien laskeminen ei siis vähennä analyysiin "laadullisuutta", vaan tuo siihen yhden lisäulottuvuuden, kuten Silverman $(1993,300)$ toteaa.
Tarkempi kuvaus analyysin toteutuksesta löytyy BeLL-raporteista (Manninen \& Meriläinen 2014). Samaa koodausohjetta ja teemoittelua käytettiin myöhemmin myös teemahaastattelujen $(\mathrm{n}=82)$ analyysissa (ks. Sgier 2014). Haastatteluissa kysyttiin osallistumisen tuottamia hyötyjä samoilla kysymyksillä, joita oli käytetty lomakkeen avokysymyksissä. Haastattelujen analyysissa ei löydetty uusia hyötyjä, joten ne vahvistavat avovastausten analyysin tulokset.

Avovastausten analyysin tulokset esitetään seuraavassa luvussa, jossa ne on yhdistetty faktorianalyysin tuloksiin (taulukko 4). Hyötyjen lisäksi analyysissa löydettiin yhteensä 3264 mainintaa erilaisista taidoista ja osaamisalueista, joista useimmin mainittiin kielitaidon paraneminen (551) ja yleistiedon lisääntyminen (525). Harvinaisempia olivat ympäristötietoisuuden (25) ja lukuharrastuksen (34) sekä kirjoitusharrastuksen (34) lisääntyminen. Jonkun taidon tai osaamisalueen kehittymisen mainitsi siis $73,5 \%$ vastaajista.

\section{Monimenetelmällinen näkökulma hyötyihin}

BeLL-tutkimuksessa käytettiin monimenetelmällistä (mixed methods) lähestymistapaa. Lähtökohtana oli määrällisen (lomakeväittämät, $n=8646$ ) ja laadullisen aineiston (avokysymykset ja teemahaastattelut) hyödyntäminen syvällisen kokonaiskuvan luomiseksi aikuisopiskelun hyödyistä. Myös tulosten luotettavuuden kannalta monimenetelmällisyys oli perusteltu lähestymistapa. Tavoitteena oli hyödyntää Masonin (2006) kuvaamista monimenetelmällisen tutkimuksen strategioista erityisestä kahta, 'lähiku- 
van' saamista ja 'erilaisten samaa asiaa eri näkökulmasta lähestyvien kysymysten tekemistä'. Edellinen täydentää tilastoanalyysin antamaa kokonaiskuvaa tuomalla mukaan paremmin yksilötason kokemuksia ja merkityksiä, jälkimmäinen tuo lisäymmärrystä ja syvennystä hyötyjen luonteesta ja linkittymisestä opiskelukokemuksiin. Eri menetelmien ja aineistojen käyttö toteuttaa siten triangulaation ja täydentävyyden (complementarity) periaatetta (Hammond 2005, 247-250). Täydentävyys mahdollistaa tulosten syventämisen, havainnollistamisen ja selventämisen. Teemahaastattelut myös mahdollistivat hyötyjen ja niiden syntyprosessin arvioinnin vastaajien elämäntilanteen kontekstissa. Laadullinen aineisto myös validoi hyvin tilastollisen analyysin tuottamat tulokset, sillä samat hyödyt nousivat esiin kaikissa aineistoissa.

Taulukko 4 kuvaa, miten laadullista avovastausten analyysia voi käyttää tilastollisten tulosten syventämiseen. Tulosten vertailu mahdollistui, koska avovastausten analyysin aikana huomattiin siinä löydettyjen teemojen (koettujen hyötyjen) asettuvan luonnostaan teoreettisten käsitteiden ja edelleen faktorianalyysissa löydettyjen päähyötyjen alle. Taulukossa on vertailtu myös tulosten määrällistä painotusta. Faktoreiden pohjalta tehtyjen summamuuttujien osalta on merkitty "paljon enemmän" (7) vastanneiden osuus ja laadullisen analyysin osalta kunkin hyödyn spontaanisti maininneiden vastaajien osuus.

Faktoritasolla paljon muutosta kokeneiden ja kyseisen hyödyn spontaanisti maininneiden prosenttiluvut vastaavat toisiaan varsin hyvin, mutta muutamia poikkeuksiakin on. Elämänhallinta on mainittu avovastauksissa vain kaksi kertaa (0,05\% vastaajista), mutta tunnistettu lomakeväittämissä yhdeksi hyödyksi (15,8 \% kokenut sen lisääntyneen paljon). Myös perheeseen ja suvaitsevaisuuteen liittyviä hyötyjä mainittiin spontaanisti huomattavasti vähemmän kuin tunnistettiin lomakeväittämien avulla.

Eroille löytyy selityksiä. Ensinnäkin tulee muistaa kysymisen tapojen erot: avovastauksessa vastaaja kertoo mielessään parhaiten olevat kokemukset, mutta lomakeväittämien kohdalla on mahdollisuus täyttää eräänlainen "tarkistuslista", jolla voi arvioida, onko erilaisten listalle koottujen asioiden suhteen tapahtunut muutosta. Toinen selitys erityisesti elä- mänhallinta-faktorin kohdalla liittyy siihen, että kyseessä on Rotterin (1966) ulkoisen ja sisäisen kontrolliodotuksen teoriaan pohjautuva käsite ja psykologinen ilmiö. Kontrolliodotus on tiedostamaton suhtautumistapa, joka säätelee toimintaa erilaisissa tilanteissa, ja sen mittaamiseen tarvitaan psykologisissa tutkimuksissa kehitettyjä vakiintuneita väittämiä. Avovastauksissa sisäisen kontrolliodotuksen vahvistuminen näkyi kahdessa vastauksessa:

[..] selvitin mitä haluan elämässäni, ja suunnittelen nyt sen mukaan etukäteen, sen sijaan että vain reagoisin ulkoisiin tapahtumiin (ENG_OPEN_100261)

Huomasin että se [opinnoissa onnistuminen] on alku, ja jatkuva yrittäminen voi tuottaa tulosta, mahdoton voi muuttua mahdolliseksi joku päivä (RO_OPEN_500271)

Field $(2009,27)$ kuvaa samaa ilmiötä "koetuiksi vaikutusmahdollisuuksiksi tärkeissä elämän valintatilanteissa”. Sisäisen kontrolliodotuksen vahvistuminen linkittyy myös muihin hyötyihin eli itseluottamuksen, minäpystyvyyden ja koetun elämänhallinnan tunteen vahvistumiseen.

Laadulliset tulokset sekä vahvistavat (esimerkiksi muutokset koulutuskokemuksissa -faktori) että syventävät (esimerkiksi henkinen hyvinvointi -faktori) lomakekyselyn tuloksia. Koulutuskokemuksia mittaavat lomakeväittämät näyttävät toimivan hyvin, sillä lähes identtiset teemat löytyivät myös avovastausten laadullisessa analyysissa. Esimerkiksi luottamusta omaan oppimiskykyyn kuvaavat avovastauksissa mainitut opiskelutaitojen kehittyminen ja onnistumisen tunteet. Henkisen hyvinvoinnin kohdalla avovastausten teemoittelu puolestaan tuottaa paljon syvemmän ja tarkemman kuvan osallistumisen tuottamista henkistä hyvinvointia parantavista hyödyistä kuin lomakkeen kaksi yleisempää väittämää. Vastaavat teemat nousivat esiin myös haastatteluissa:

Taulukko 4. Hyötyfaktoreiden (lomakeväittämät) ja hyötyteemojen (avokysymykset) vertailu. 


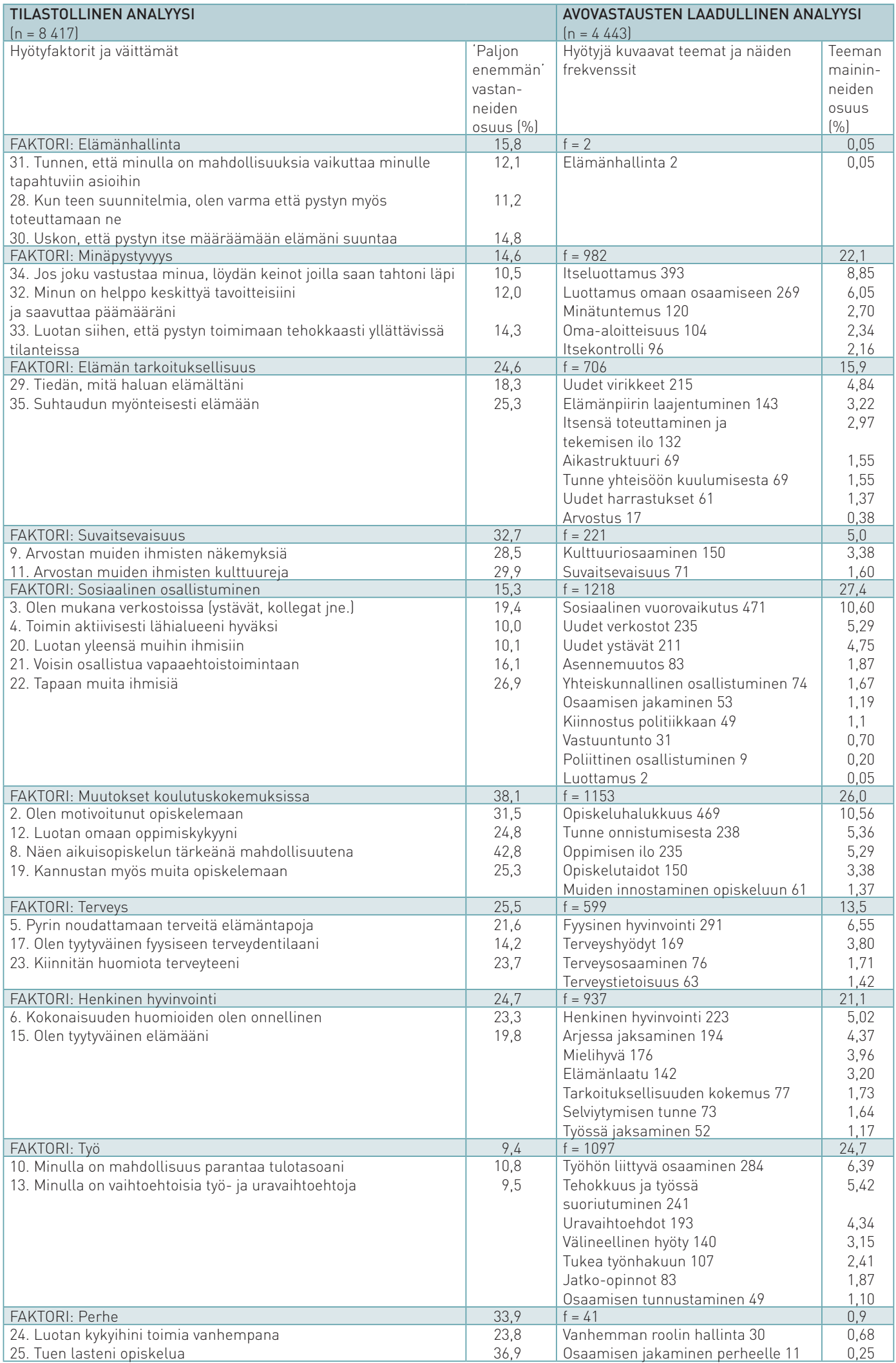


Kyllä se tää kirjoittaminen, se todella pitää niinku mielen virkeenä ja ja ja (FIN_INTERVIEW_A) ja se on semmonen rentouttava kuitenkin ja vie ajatukset pois töistä (FIN_INTERVIEW_C)

Se että tapaa siellä mukavia ihmisiä. Lähdet, menet kotiin hyvällä mielellä. Ja, totta kai tämä hyvä mieli auttaa minua jokapäiväisessä elämässä (GER_ INTERVIEW_F)

Avovastausten laadullinen analyysi tarkentaa myös työhön liittyvien hyötyjen kuvaa nostamalla esiin vastaajien itse määrittelemät palkka- tai vapaaehtoistyöhön liittyvät hyödyt (osaaminen, tehokkuus ja työssä suoriutuminen, uravaihtoehdot, välineelliset hyödyt, tuki työnhakuun, jatko-opintomahdollisuuksien avautuminen ja osaamisen tunnustaminen).

Mielenkiintoisin tulos on ehkäpä hyötyjen syntyprosessiin liittyvä vahva prosessimaisuus ja hyötyjen linkittyminen toisiinsa. Ilmiö tulee hyvin esille erityisesti haastatteluissa, mutta myös avovastauksissa ja tilastollisen aineiston rakenneyhtälömallinnuksessa (Manninen ym. [arvioitavana]). Tuloksissa nousee vahvasti esille sosiaalisen vuorovaikutuksen ja ryhmätilanteisiin osallistumisen merkitys sekä hyötynä että muiden hyötyjen syntymiseen vaikuttavana tekijänä. Sama havainto on tehty myös muissa tutkimuksissa (hyvä yhteenveto Field 2009, 26), esimerkiksi yhteisöllisyyden ja terveydentilan (Chen \& Yang 2014) ja henkisen hyvinvoinnin (Elliott, Gale, Parsons \& Kuh 2014) välillä. Haastatteluissa suomalaiset aikuisopiskelijat kuvailivat prosessia seuraavasti:

sit sillä on varmaan paljon kans merkitystä et siinä on paljon muitten ihmisten kanssa tekemisissä että. että yhdessä tekemällä tulee monella tapaa mukavampi fiilis. kui että yksin alkaa vääntämään jotakin (FIN_INTERVIEW_G)

Kyllä ne henkinen ja fyysinen [hyvinvointi] on siellä ykköspuolella. Et jos ne on kunnossa, niin sit on sosiaalisuuskin kunnossa ja ymmärtäminen ja ja ja nää pitkäjänteisyydet ja ja tota, mutta kyllä se on kyllä siellä on aika ylhäällä se oppimisenkin öö se oppimistapa, että kun sä opit ja oivallat lisää uutta, niin kyllä sekin antaa kans voimavaroja (FIN_ INTERVIEW_F).

\section{HYÖTYJEN SYNTYMISEEN}

NÄYTTÄISI VAIKUTTAVAN

ERITYISESTI OPISKELUN

\section{OMAEHTOISUUS ELI}

VAPAAEHTOISUUS.

Monimenetelmäinen lähestymistapa siis mahdollistaa sen, että ei-ammatillisen koulutuksen laajemmista hyödyistä syntyy tarkempi ja syvällisempi kuva ja samalla vahvistuu tulosten validiteetti aineistotriangulaation kautta. Laadullinen aineisto myös mahdollistaa paremmin hyötyjen syntyprosessien tunnistamisen, joka olisi vaikeaa pelkän tilastollisen kyselyaineiston avulla.

\section{JOHTOPÄÄTÖKSET}

BeLL-tutkimuksen tulokset osoittavat, että vapaan sivistystyön opintoihin osallistuneista suurin osa tunnistaa monia erilaisia opiskelun tuottamia hyötyjä. Avovastausten ja teemahaastattelujen laadullinen analyysi vahvistaa ja syventää tilastollisen analyysin tuloksia, ja osoittaa että osallistujat tunnistavat näitä hyötyjä ja osaavat myös kuvata sanallisesti niitä ja niiden kehittymistä.

Ryhmävertailut (ks. Manninen \& Meriläinen 2014) kertovat joistakin tilastollisesti merkittävistä eroista koettujen hyötyjen ja esimerkiksi sukupuolen, iän, koulutustason ja kurssityypin osalta, mutta käytännössä erot ovat varsin pieniä tai arvattavia. Esimerkiksi miehet kokevat hieman enemmän työhön liittyviä hyötyjä ja naiset puolestaan perheeseen liittyviä hyötyjä, ja terveyteen ja liikuntaan liittyvät kurssit lisäävät hieman enemmän fyysistä hyvinvointia. Mielenkiintoisempaa on, että muillakin kurssityypeillä on vastaavanlaisia terveysvaikutuksia. Haastatteluaineiston ja joidenkin avovastausten perusteella kävi ilmi, että lisääntynyt usko omiin vaikuttamismahdollisuuksiin ja esimerkiksi elämänpiirin laajentuminen johtaa myös terveyskäyttäytymisessä tapahtuviin muutoksiin. Taustalla näyttäisi olevan positiivisempi asennoituminen ja usko mahdollisuuksiin vaikuttaa omaan elämään, mikä on havaittu 
myös aikaisemmissa tutkimuksissa terveydentilan paranemista selittävänä tekijänä (Tuijnman 1990; Field 2009, 9), kuten myös yleinen hyvinvoinnin lisääntyminen (esim. Desjardins 2008).

Myös joitakin maakohtaisia eroja löytyi vastaajien taustatekijöiden ja kurssityypin vakioinninkin jälkeen, mutta niiden tulkinta ja selittäminen vaatisi maakohtaisia koulutusjärjestelmää ja koulutuspolitiikkaa vertailevia lisäaineistoja.

Koulutustason mukainen vertailu osoittaa, että mitä matalampi koulutustaso vastaajalla on, sitä enemmän aikuisopiskelu tuottaa muutoksia eli hyötyjä. Siten vapaa sivistystyö voi madaltaa kuilua erilaisen koulutustaustan omaavien sosiaaliryhmien välillä ja tasoittaa lapsuuden ja nuoruuden koulutusmahdollisuuksien eroja. Opiskelumotivaation ja itseluottamuksen lisääntyminen lisää erityisesti vähemmän koulutettujen todennäköisyyttä osallistua jatkossakin aikuiskoulutukseen, joten harrastustavoitteinen opiskelu toimii matalan kynnyksen osallistumismahdollisuutena, joka voi innostaa myös jatko-opintoihin (vrt. Eurydice 2015, 58).

Hyötyjen syntymiseen näyttäisi vaikuttavan erityisesti opiskelun omaehtoisuus eli vapaaehtoisuus, mikä lisää ei-ammatillisen koulutuksen koulutuspoliittista merkitystä. Pienet onnistumisen kokemukset mielekkäiksi koetuissa asioissa heijastuvat välittömästi opiskelijaminäkuvan paranemiseen ja opiskelumotivaation lisääntymiseen. Tärkeitä ovat ryhmä, vuorovaikutus ja tunne kuulumisesta johonkin yhteisöön. Tulokset siten vahvistavat Decin ja Ryanin motivaatioteoriaa (Deci \& Ryan 2008; Baeten, Dochy \& Struyven 2013). Erityisesti erilaisen sosi-

aalisen tai etnisen taustan omaavista opiskelijoista muodostuvat sekaryhmät edistävät suvaitsevaisuutta ja osaamisen jakamista. Vastaajat korostavat myös kouluttajan osaamisen ja persoonan merkitystä, ja opiskelun luoma aikastruktuuri lisää tunnetta oman elämän hallinnasta.

Koulutuspoliittisesti tulokset tulisi huomioida siten, että sekä kansallisella että Euroopan tasolla eiammatilliset eli suomalaisittain vapaan sivistystyön tyyppiset opinnot huomioitaisiin paremmin koulutusrakenteissa, tarjonnassa ja aikuisten opinto-ohjauksessa (vrt. Eurydice 2015, 58 ja Rubenson 2013). Euroopan tasolla ei-ammatillisen koulutuksen kehittämistä voisi edistää luomalla selkeämpi ja yhtenäinen käsitteistö, jotta toiminnan arviointi, tutkimus, tilastointi ja rakenteiden kehittäminen olisi systemaattisempaa.
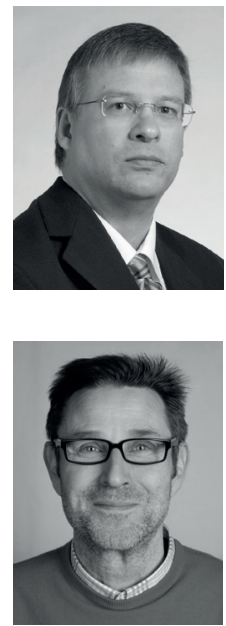

Jyri Manninen aikuiskasvatustieteen professori Kasvatustieteiden ja psykologian osasto Itä-Suomen yliopisto

Matti Meriläinen yliopistonlehtori Kasvatustieteiden ja psykologian osasto Itä-Suomen yliopisto 
Baeten, M., Dochy, F. \& Struyven, K. (2013). The effects of different learning environments on students' motivation for learning and their achievement. British Journal of Educational Psychology (2013), 83. 484-501.

Boateng, S. K. (2009). Significant country differences in adult learning. Eurostat Statistics in focus 44/2009. http://epp.eurostat.ec.europa.eu/statistics_ explained/index.php/Lifelong_learning_statistics

Brasset-Grundy, A. (2004). Family life and learning. In: T. Schuller, J. Preston, C. Hammond, A. BrassetGrundy \& J. Bynner (Eds.): The benefits of learning. The impact of education on health, family life and social capital. London and New York. 80-98.

Brown, T. A. (2006). Confirmatory Factor Analysis for Applied Research. New York, NY: The Guilford Press.

Cervone, Artisitco \& Berry (2006). Self-efficacy and Adult Development. In: Hoare, C. (Ed.): Handbook of Adult Development and Learning. New York.

Chen, D. \& Yang, T-C. (2014). The pathways from perceived discrimination to self-rated health: an investigation of the roles of distrust, social capital, and health behaviours. Social Science \& Medicine 104 (2014), 64-73.

Côté, J. E. (2005). Identity capital, social capital and the wider benefits of learning: generating resources facilitative of social cohesion. London Review of Education 3(3).

Deci, E. \& Ryan, R. (2008). Facilitating Optimal Motivation and Psychological Well-Being Across Life's Domains. Canadian Psychology, 49(1), 14-23.

Desjardins, R. (2003). Determinants of Economic and Social Outcomes from a Life-Wide Learning Perspective in Canada. Education Economics 11(1).

Desjardins, R. (2008). Researching the links between education and well-being. European Journal of Education 43(1).

Elliott, J., Gale, C., Parsons, S. \& Kuh, D. (2014). Neighbourhood cohesion and mental wellbeing among older adults: a mixed methods approach. Social Science \& Medicine 107, 44-51.

Eurydice (2007). Non-vocational adult education in Europe. Executive summary of national information on Eurybase. Working document. European Commission, Directorate-General for Education and Culture.

Eurydice (2015). Adult Education and Training in Europe: Widening Access to Learning Opportunities. Eurydice Report. Luxembourg: Publications Office of the European Union.
Feinstein, L., \& Hammond, C. (2004). The contribution of adult learning to health and social capital. Wider Benefits of Learning, Research Report No. 8. London: Institute of Education

Feinstein, L. \& Budge, D. (2007). Seeing the benefits of learning. Adults Learning. June 2007, 20-22.

Feinstein, L., Budge, D., Vorhaus, J. \& Duckworth, K. (2008). The social and personal benefits of learning: A summary of key research findings. London: Centre for Research on the Wider Benefits of Learning.

Field, J. (2005). Social Capital and Lifelong Learning. Bristol: Policy Press.

Field, J. (2009). Well-being and happiness. IFLL Thematic Paper 4. Leicester: NIACE.

Gläser, J. \& Laudel, G. (2013). Life With and Without Coding: Two Methods for Early-Stage Data Analysis in Qualitative Research Aiming at Causal Explanations. Forum Qualitative Sozialforschung / Forum: Qualitative Social Research, 14(2), Art. 5. http://nbn-resolving.de/urn:nbn:de:0114-fqs130254.

Hammond, C. (2005). The wider benefits of adult learning: an illustration of the advantages of multimethod research. International Journal of Social Research Methodology 8(3), 239-255.

Hedt, B. \& Pagano, M. (2010). Health indicators: Eliminating bias from convenience sampling estimators. Statistics in Medicine 30(5), 560-568.

Hoskins, B. \& Crick, R. D. (2010). Learning to Learn and Civic Competences: different currencies or two sides of the same coin? European Journal of Education, 45(1), 121-137.

Jarvis, P. (2014). From adult education to lifelong learning and beyond. Comparative Education 50(1), 45-57.

Jarvis, P. \& Griffin, C. (Eds.) (2003). Adult and Continuing Education: Major Themes in Education. Vol. 1 Liberal Adult Education, Part 1. London: Routledge.

Kouvo, A. (2011). The Sources of Generalized Trust and Institutional Confidence in Europe. Research on Finnish Society 3(1), 29-40.

Kumpulainen, T. (toim.) (2008). Aikuiskoulutuksen vuosikirja. Tilastotietoja aikuisten opiskelusta 2006 Opetusministeriön julkaisuja 2008:22.

Laginder, A-M., Nordvall, H. \& Crowther, J. (2013). Popular Education, Power and Democracy. Swedish Experiences and Contributions. Leicester: NIACE.

Litster, J., Brooks, G. and Burton, M. (2010). European Adult Learning Glossary, Level 2. Brussels: European Commission. 
Micari, M. (2003). Against the Norm: Liberal Adult Education in an Age of Vocationalism. The Journal of Continuing Higher Education, 51(3), 27-34.

Makola, S. \& Van den Berg, H. (2008) Meaning/Purpose in Life and related constructs: A literature review. International Journal of Existential Psychology \& Psychotherapy, 2(2), 1-7.

Manninen, J. (2004). Mielikuvat ohjaavat aikuisten osallistumista koulutukseen. Aikuiskasvatus 24(3), 196-205.

Manninen, J. \& Luukannel, S. (2008). Omaehtoisen aikuisopiskelun vaikutukset. Vapaan sivistystyön opintojen merkitys ja vaikutukset aikuisten elämässä. Helsinki: VSY.

Manninen, J. (2010a). Wider Benefits of Learning within Liberal Adult Education System in Finland. In Horsdal, M. (Ed.). Communication, Collaboration and Creativity: Researching Adult Learning. Odense: Syddansk Universitetsforlag.

Manninen, J. (2010b). Sopeuttavaa sivistystyötä? Aikuiskasvatus 20(3), 164-174.

Manninen, J. \& Meriläinen, J. (2014). Benefits of Lifelong Learning - BeLL Survey Results. Bonn: DIE. http://www.bell-project.eu/cms/?page_id=10

Manninen, J., Kil, M., Thöne-Geyer, B., Meriläinen, M., Sgier, I., Mallows, D. \& Fleige, M. (arvioitavana) Wider Benefits of non-vocational adult learning - a structural equation model.

Mason, J. (2006). Six strategies for mixing methods and linking data in social science research. NCRM Working Paper Series, 4/06, ESRC National Centre for Research Methods.

Merriam, S.B. \& Kee, Y. (2014). Promoting community well-being: the case for lifelong learning for older adults. Adult Education Quarterly 64(2), 128-144.

Motschilnig, R. (2012). Wider Benefits of Adult Education - An Inventory of Existing Studies and Research. In Adult Education and Development. DVV International, European Association for the Education of Adults, 79-89.

Muthén, L. K. \& Muthén, B. O. (2010). MPlus User's Guide (6th ed.). Los Angeles, CA: Muthén \& Muthén

Nordvall, H. (2002). Folkbildning som mothegemonisk praktik? Utbildning och demokrati 11(2), 15-32.

Newton, K. \& Zmerli, S. (2011). Three Forms of Trust and Their Association, European Political Science Review, 3(2), 169-200

Nummela O, Sulander T, Karisto A, Uutela A. (2009). Self-rated health and social capital among aging people across the urban-rural dimension. International Journal of Behavioral Medicine 16(2), 189-94.
OECD (2007). Understanding the Social Outcomes of Learning. Paris: OECD.

OECD (2010). Improving Health and Social Cohesion through Education. Paris: OECD

Pintrich, P. (1988). A process-oriented view of student motivation and cognition. In: Stark \& Mets (Eds.), Improving teaching and learning through research. New Directions for Teaching and Learning, no. 57. San Francisco: Jossey-Bass.

Preston, J. \& Feinstein, L. (2004). Adult education and attitude change. London. Centre for Research on the Wider Benefits of Learning.

Rotter, J. B. (1966). Generalized expectancies for internal versus external control of reinforcement. Psychological Monographs: General and Applied 80(1), 1-28.

Rubenson, K. (1979). Recruitment to Adult Education in the Nordic Countries - Research and Outreaching Activities. Stockholm Institute of Education, Department of Educational Research, Reports on Education and Psychology nr. 3.

Rubenson, K. (2006). The Nordic model of Lifelong Learning. Compare 36(3), 327-341.

Rubenson, K. (2013). Towards lifelong learning for all in Europe: understanding the fundamental role popular education could play in the European Commission strategy. In: Laginder, A-M., Nordvall, H. \&

Crowther, J. (2013). Popular Education, Power and Democracy. Swedish Experiences and Contributions. Leicester: NIACE.

Ryff, C. (1989). Happiness is everything, or is it? Explorations on the meaning of psychological wellbeing. Journal of Personality and Social Psychology, 57, 1069-1081.

Saldana, J. (2013). The Coding Manual for Qualitative Researchers. London: SAGE.

Schuller, T., Brassett-Grundy, A., Green, A., Hammond, C. \& Preston, J. (2002). Learning, Continuity and Change in Adult Life, Wider Benefits of Learning Research Report No. 3. Centre for Research on the Wider Benefits of Learning. London: Institute of Education.

Schuller, T. \& Desjardins, R. (2010): The wider benefits of adult education. In International Encyclopedia of Education (229-233) Oxford.

Schuller, T. \& Watson, D. (2009). Learning through life. Inquiry into the future for lifelong learning. Leicester: NIACE.

Sgier, I. (2014). Qualitative Data Analysis Report Analysis of the BeLL interviews in 10 countries: overall report. Bonn: DIE. http://www.bell-project. $\mathrm{eu} / \mathrm{cms} /$ ?page_id $=10$ 
Silverman, D. (1993). Interpreting qualitative data. Methods for analysing talk, text and interaction. London: Sage.

Strauss, A. \& Corbin, J. (1998). Basics of qualitative research: Techniques and procedures for developing grounded theory. Thousand Oaks, CA: Sage.

Sudman, S., Sirken, M. \& Cowan, C. (1988). Sampling rare and elusive populations. Science 240(4855), 991-996.

Sutcliffe, M. (2014). The origins of the 'two cultures' debate in the adult education movement: the case of the Working Men's College (c.1854-1914). History of Education: Journal of the History of Education Society, 43(2), 141-159.

Tuijnman, A. (1990). Adult Education and the Quality of Life. International Review of Education 36(3), 283-298.

Zimbardo, P. G. (1985). Psychology and life. Boston: Ally \& Bacon

\section{VIITTEET}

1 2011-2014 toteutettua projektia koordinoi Deutsches Institut für Erwachsenenbildung (DIE) ja rahoitti Euroopan Komissio (Lifelong Learning Programme, Studies and Comparative Research, KA 1 No. 519319-LLP-1-2011-1-DE-KA1-KA1SCR).

2 Suomi, Espanja, Englanti, Saksa, Sveitsi, Italia, Tšekki, Slovenia, Romania ja Serbia.

3 Esimerkiksi historia- ja kulttuuriaiheisia kursseja oli tarjolla paljon Englannissa ja Italiassa, mutta ei juuri lainkaan Suomessa, jossa taas kädentaidot ja erityisesti laulaminen olivat yleisempiä kuin muissa maissa

4 Tilastolliset analyysit tehtiin SPSS-19.0 ja MPlus6.0 (Muthén \& Muthén 2010) -ohjelmilla.

5 Summamuuttujat on skaalattu kokonaisluvuiksi seuraavasti: 1 = 1 (paljon vähemmän),

$1.1--2$ = 2 (vähemmän),

$2.1--3=3$ (hieman vähemmän), $3.1--4=4$ (ei muutosta), $4.1--5=5$ (hieman enemmän), $5.1--6=6$ (enemmän) ja $6.1--7=7$ (paljon enemmän). 